\title{
Repurchasing an Environmental Related Crisis Experienced Automobile Brand: An Examination in the Context of Environmental Consciousness, Brand Trust, Brand Affect, and Resistance to Negative Information
}

Beyza GÜLTEKIN (https://orcid.org/0000-0002-6797-864X), Hacettepe University, Turkey; beyza@hacettepe.edu.tr

Seyit İhsan KILIÇ (https://orcid.org/0000-0002-2705-897X), Hacettepe University, Turkey; ihsankilic@gmail.com

\section{Çevre ile ilgili bir Kriz Deneyimlemiş bir Otomobil Markasını Tekrar Satın Alma Niyeti: Çevre Bilinci, Marka Güveni, Marka Duygusu ve Olumsuz Bilgiye Karşı Direnç Çerçevesinde İncelenmesi}

\begin{abstract}
This study explores the direct effects of brand trust and environmental consciousness on the intention to repurchase a brand; tests the indirect impacts of brand affect and resistance to negative information in the effect of brand trust on intention to repurchase. The data collected from 110 current users of a particular brand of an automotive company that has recently faced an environmental crisis. SEM and process analysis are used to test the hypotheses. Brand trust positively affects repurchase intention, whereas environmental consciousness does not. Brand affect and resistance to negative information are mediators. For an environmental crisis experienced brand; this study clarifies the significance of brand related concepts (e.g., brand trust, brand affect) and resistance to negative information instead of environmental consciousness in an emerging market, Turkey.

Keywords

Environmental Crisis, Environmental Consciousness, Brand Trust, Brand Affect, Resistance to Negative Information, Repurchase Intention.

JEL Classification Codes : $\quad$ M10, M19, M30, M31.

\section{$\ddot{\mathbf{O} z}$}

Marka güveninin ve çevre bilincinin bir markayı tekrar satın alma niyeti üzerindeki doğrudan etkilerini araştırmak, marka güveninin yeniden satın alma niyeti üzerindeki etkisinde marka duygusu ve olumsuz bilgiye karşı direncin dolaylı etkilerini test etmek amaçlanmaktadır. Veriler çevresel krizle karşı karşıya kalan bir otomotiv firmasının belirli bir markasını kullanan 110 katılımcıdan toplanmıştır. Hipotezler SEM ve process analizi ile test edilmiştir. Marka güveni, tekrar satın alma niyetini olumlu yönde etkilerken, çevre bilinci etkilememiştir. Marka duygusu ve olumsuz bilgilere karşı direncin aracı etkisi bulunmaktadır. Çevresel kriz yaşamış bir marka için; bu çalışma, gelişmekte olan bir ülke olan Türkiye'de çevre bilinci yerine marka ile ilgili kavramların (örn. marka güveni, marka duygusu) ve olumsuz bilgilere karşı direncin önemli olduğunu ortaya koymaktadır.
\end{abstract}

Anahtar Sözcükler Çevresel Kriz, Çevre Bilinci, Marka Güveni, Marka Duygusu, Olumsuz Bilgiye Karşı Direnç, Tekrar Satın Alma Niyeti. 
Gültekin, B. \& S.İ. Kılıç (2022), "Repurchasing an Environmental Related Crisis Experienced

Automobile Brand: An Examination in the Context of Environmental Consciousness, Brand

Trust, Brand Affect, and Resistance to Negative Information”, Sosyoekonomi, 30(51), 241-260.

\section{Introduction}

Environmental problems occur since people have consumed the environment for centuries for different purposes, methods, and dimensions (Krause, 1993). Although the early environmental issues are not a significant threat to society (Krause, 1993), especially after the Industrial Revolution, the environmental problems increase significantly and become dangerous (Daly \& Zannetti, 2007).

In this context, Abratt and Sacks (1988) state that criticisms arise to the purchases made by customers without considering the social benefit. Along with the criticisms stated, a societal marketing orientation arises, suggesting that researchers should also address the social and ethical perspective (Takas, 1974). Societal marketing emphasizes that managers should take the environment into account in producing goods and services (Prothero, 1990). Within the societal marketing approach framework, the consumers' environmental consciousness level gains importance.

Environmentally conscious consumers have an awareness of environmental problems. These consumers are the people who support and may be able to solve environmental issues (Ariffin et al, 2016). Environmental consciousness levels of consumers worldwide are increasing (Schlegelmilch et al., 1996). Therefore, consumers' purchasing intention for environmentally friendly products is also growing (Kalafatis et al., 1999). Despite the increase in the purchase intention of environmentally conscious consumers and environmentally friendly products, some brands may come to the fore with the damage they cause to the environment. In such cases, brands may face crises due to companies' activities that harm the environment and nature (Mitroff et al., 1987).

In this case, consumers with high environmental consciousness may negatively affect their intention to repurchase the brand after the crisis. The level of environmental consciousness affects consumer behaviour (Garvey \& Bolton, 2017). However, no specific study in the literature examines this direct impact. Investigating this issue is also crucial for companies' crisis management. Environmental brand crises that may arise in societies with high environmental consciousness can cause more harm to the company compared to crises that may arise from societies with low environmental consciousness.

Furthermore, brand crises can negatively affect the continuity and profitability, putting the future of the relevant brand at risk (Pace et al., 2017). For this reason, crises can pose a threat to brands and affect the brand negatively (Claeys et al., 2010). However, the brand trust developed before the crisis can protect the brand against the crisis and the negativities arising from the crisis (Peltekoğlu, 2014: 469). Trust is essential in developing a positive brand-customer relationship (Delgado-Ballester \& Luis Munuera-Alemán, 2001). According to Upamannyu, Bhakar, and Gupta (2015) brand trust is a long-term experience (Upamannyu et al., 2015). The brand and customers rely on the consumers' beliefs and 
reliance on the brand (Chaudhuri \& Holbrook, 2001), which might protect the company during and after crises.

In the literature, brand trust is generally considered together with the concept of brand affect (Upamannyu et al., 2015) since brand affect is an approach that can complement brand trust. Brand affect is the positive emotion potential (Chaudhuri \& Holbrook, 2001) that the brand can create in the consumer and consists of feelings that develop instantly (Upamannyu et al., 2015). Firms may need brand affect as well as brand trust in a crisis.

In addition, crises faced by brands can cause negative information about brands (Dawar \& Lei, 2009). Negative information can damage its reputation and negatively affect its sales (Eisingerich et al., 2011). In such a situation, consumers' reaction to negative information is essential. For example, in some cases, consumers can resist negative information for several reasons. Namely, a socially responsible, customer-oriented, serviceoriented, or sensitive to environmental issues may be less affected by negative information about itself (Eisingerich et al., 2011), which might be a result of brand trust. More specifically, the brand trust that affects resistance to negative information (Turgut \& Gultekin, 2015) might shelter the brand in times of crisis. In other words, brand trust can also lead to consumer non-adoption of negative information resulting from the brand crisis, which might increase the likelihood of repurchasing the same brand. However, the number of studies examining the possible effects of negative information emerging for a brand or company and consumers' reactions to this information in question is limited (Ahluwalia, Burnkrant, \& Unnava, 2000). Therefore, in crises, companies and researchers need to investigate the impact of brand trust on resistance to negative information and resistance to negative information on purchase intention.

Investigating environmental consciousness and brand trust in the context of realworld brand crises firstly, contributes to the literature and practitioners by collecting data in an emerging market, Turkey. Secondly, although these underlying relationships between brand trust, brand affect, resistance to negative information, and repurchase intention is vital for a company's success, up to our knowledge this proposed model has not been tested internationally and nationally. The findings of this study would help managers in Turkey during their allocation of the marketing budget and preparation of related promotional messages.

In this framework, this paper aims to measure the direct effects of brand trust and environmental consciousness on the intention to repurchase a brand. Then this study examines the related mediating effects of brand affect and resistance to negative information in the impact of brand trust on intention to repurchase a specific automobile brand that has experienced an environmental crisis. In the last section, results, limitations of the study, suggestions for future research, and suggestions for managers are given. 
Gültekin, B. \& S.İ. Kılıç (2022), "Repurchasing an Environmental Related Crisis Experienced

Automobile Brand: An Examination in the Context of Environmental Consciousness, Brand

Trust, Brand Affect, and Resistance to Negative Information”, Sosyoekonomi, 30(51), 241-260.

\section{Conceptual Framework}

\subsection{Environmental Consciousness - Repurchase Intention Linkage}

Ethical issues are related to the environmental impact on the purchasing behavior of consumers (Newholm \& Shaw, 2007). Consumers' value judgments are a vital tool for predicting purchasing intentions (Ariffin et al., 2016). Environmentally conscious consumers are the "people who are aware of environmental problems, who support or may be able to solve these problems" (Ariffin et al., 2016: 393).

In the literature, there are studies (Ariffin et al., 2016; Menon et al., 1999) showing that environmental consciousness affects repurchase intention. In addition, environmentally conscious consumers purchase environmentally friendly products more and are prone to pay higher prices for these products (Ariffin et al., 2016; Kong et al., 2014). Consumers' environmental consciousness also positively affects their intention to repurchase environmentally friendly products (Menon et al., 1999). Therefore, environmental consciousness enables consumption being right and good for society and individuals (Lin et al., 2015).

On the other hand, crises faced by brands can affect consumer attitudes and behaviours (Yannopoulou et al., 2011). Many studies (Lin et al., 2011; Souiden \& Pons, 2009) emphasize that various crises faced by firms harm consumer purchase intention. In addition, the non-environmentally friendly activities of brands can negatively affect the purchasing preferences of consumers with high environmental consciousness (Lin et al., 2015). As a result, the crisis and its aftermath negatively affect sales (Carter, 1997). Kong et al. (2014) mention that $77 \%$ of the participants stated that they do not buy the products of a specific brand because it harms the environment. The greenhouse gas emission and fuel consumption levels of automobiles are essential decision-making criteria for potential and existing automobile users (Chowdhury et al., 2016).

Based on this information, the purchasing intention of environmentally conscious consumers towards brands facing the crisis may be adversely affected due to environmental consciousness. That is to say, the environmental consciousness of the consumers may harm the intention of purchasing the company's products faced with an environmental crisis. The hypothesis proposed is as follows.

H1. Environmental consciousness negatively affects the intention to repurchase the brand that has experienced an environmental crisis.

\subsection{Brand Trust - Repurchase Intention Linkage}

Trust is the mutual belief that the parties will not take advantage of each other's weaknesses (Barney \& Hansen, 1994). Trust is the desire or expectation to rely on the other party in risky or uncertain situations (Matzler et al., 2008). Brand trust enables customers to purchase the brand in question by reducing uncertainty for customers (Mishra et al., 2016). 
Gültekin, B. \& S.İ. Kılıç (2022), "Repurchasing an Environmental Related Crisis Experienced Automobile Brand: An Examination in the Context of Environmental Consciousness, Brand

Trust, Brand Affect, and Resistance to Negative Information", Sosyoekonomi, 30(51), 241-260.

In other words, while consumers are making purchasing decisions, they can choose the brands they trust to reduce the risk (Yannopoulou et al., 2011).

There is a positive impact of brand trust on brand loyalty (Chaudhuri \& Holbrook, 2001; Orzan et al., 2016), brand commitment (Delgado-Ballester \& Luis Munuera-Alemán, 2001), and intention to repurchase (Fang et al., 2011; Lin et al., 2011). Brand trust also causes customers to buy large amounts (Mishra et al., 2016). Customers buy the brands they trust more often (Chaudhuri \& Holbrook, 2001). Relying on the commitment-trust theory (Morgan \& Hunt, 1994), brand trust is critical in consumers' purchasing decisions and commitment. According to this information, it can be argued that consumers would continue buying after the crisis due to brand trust. Thus, another hypothesis suggested is as follows:

H2. Brand trust positively affects the repurchase intention of the brand that has experienced an environmental crisis.

\subsection{Mediating Role of Brand Affect between Brand Trust and Repurchase Intention}

\section{Brand Trust-Brand Affect Linkage}

Brand affect refers to the relationship between the brand and the consumer (Upamannyu et al., 2015). Having a high brand affect means that the consumer has a good impression and feeling about the brand and glorifies the brand in her/his mind (Mishra et al., 2016). Experiencing a brand can establish an emotional connection between the customer and the brand due to the brand affect (Chaudhuri \& Holbrook, 2001).

Consumers can choose the product they approach more emotionally due to the low risk attached (Mishra et al., 2016). This low risk perception and positive feelings might be due to brand trust. Kabadayi \& Koçak Alan (2012) stated the difference between brand trust and brand affect, as the former being the cognitive component that needs a long time and thought to occur. The latter being the emotional response that is more impulsive and spontaneous. Orzan et al. (2016) state that as consumers trust brands, they develop emotional attachments and find that brand affect occurs due to their trust in the brand. Therefore, brand affect might stem from the brand trust.

\section{Brand Affect-Repurchase Intention Linkage}

Emotions and feelings can have a significant impact on customer preferences (Westbrook, 1987). Chaudhuri \& Holbrook (2001) mention that consumers tend to buy brands that make them happy, entertained, and delighted. Similar to this view, brand affect has a positive impact on purchasing (Matzler et al., 2006). For example, with the impact of the brand affect or when consumers have an emotional bond with one of the restaurants they visit, consumers prone to pay a high price for the restaurant and visit this restaurant frequently (Chaudhuri \& Holbrook, 2001). In addition to these, brand affect positively influences brand loyalty (Chaudhuri \& Holbrook, 2001, 2002). Brand loyalty mitigates the 
harmful effects of a crisis faced by a brand on customers' purchase intention (Park \& Lee, 2013). For this reason, even after crises the brand affect would positively influence the repurchase intention.

Thus, we expect that the brand trust would positively influence brand affect, which in turn has a positive impact on the repurchase intention, and the hypothesis formed is as follows:

H3. Brand affect has a mediating role between brand trust and intention to repurchase the brand.

\subsection{Mediating Role of Resistance to Negative Information between Brand Trust and Repurchase Intention}

\section{Brand Trust-Resistance to Negative Information Linkage:}

Companies need to focus on long-term goals in a competitive environment to establish relationships with consumers, rather than short-term and profit-oriented goals (Grönroos, 1997). Trust is critical for firms to establish a long-term and strong relationship with consumers (Matzler et al., 2008). In addition, trust is an essential factor that shapes the brand-customer relationship (Mishra et al., 2016).

Brand trust is an important phenomenon, especially in uncertainty or fear of opportunism (Laroche et al., 2012). Brand trust helps reduce uncertainties in consumers' minds (North, 2011). The role of trust in such situations is to reduce consumer concerns and make them feel safe towards brands (Laroche et al., 2012). Consumers consider brand trust in their purchasing process and the whole process of interacting with the brand (DelgadoBallester et al., 2003).

Trust created before the crisis protects the brand against the crisis's adverse effects (Peltekoğlu, 2014: 457). Trust is when one party believes that the other will take an action that will lead to positive results (Morgan \& Hunt, 1994). In other words, trust is the belief that the parties will not take action that will have negative consequences for each other.

Based on this information, the possible effect of brand trust on resistance to negative information becomes crucial. Eisingerich et al. (2011) argue that corporate social responsibility, customer orientation, and service quality protect brands against negative information. Accordingly, consumers can trust a brand that is socially responsible, customeroriented, service-oriented, or sensitive to environmental issues and is less affected by negative information about this brand.

The trust and reputation formed due to the company's communication strategies in the pre-crisis period can reduce the harmful effects of the crisis (Peltekoğlu, 2014: 457). In addition, during the crisis, the brand trust established previously can protect the firm against the adverse effects of the crisis (Peltekoğlu, 2014: 469). Therefore, if consumers' trust in a 
brand is high, they can be expected to resist to negative information caused by the crisis that arose for that brand. Similarly, Turgut and Gultekin (2015) show that brand trust positively affects resistance to negative information.

\section{Resistance to Negative Information-Repurchase Intention Relationship Linkage}

Resistance to negative information is the fact that the general opinion of consumers about any brand is not affected adversely by unfavourable messages (Eisingerich et al., 2011). Consumers can resist unfavourable information for various reasons. According to Liu (2006), the value of the information can affect the resistance to negative information. Also, consumers' strong relationship with the brand can be a valid reason to resist negative information (Aaker et al., 2004).

Consumers are frequently exposed to a variety of information. For this reason, they are often selective by eliminating some of the information and tend to use only the necessary information (Dawar \& Pillutla, 2000). Consumers' judgments about products and their intention to try new products can be positively or negatively affected by the information obtained (Liu, 2006). One of the types of information that consumers utilize is negative information that can arise about the brand. Negative information can damage the company's reputation and negatively affect the company sales (Eisingerich et al., 2011). Unfavourable information and how firms deal with negative information affect customers' purchasing decisions (Ahluwalia et al., 2000). Consumers regard negative information as more informative or explanatory than positive information (Ahluwalia et al., 2000). Therefore, managing negative information is vital for companies.

Negative information about a product can reduce product sales (Chevalier \& Mayzlin, 2006). Furthermore, the effect of negative information on reducing product sales is stronger than the potential positive effect of positive information on product sales (Chevalier \& Mayzlin, 2006). As the resistance to negative information reduces, the consumers' intention to boycott diminishes (Kang et al., 2021). Based on this information, due to resistance to negative information, consumers might repurchase the same brand that has experienced an environmental crisis. Therefore, the following hypothesis is proposed as follows:

H4. Resistance to negative information has a mediator role on the positive influence of brand trust on the intention to repurchase the brand.

\subsection{Brand Trust - Brand Affect - Resistance to Negative Information - Repurchase Intention Linkage}

Consumers' emotions and feelings towards the brand constitute the consumer-brand relationship (Chen-Yu et al., 2016). Consumers use emotions as the source of information about the brand (Mishra et al., 2016). In other words, consumers can act in line with their feelings towards brands. Furthermore, brand affect positively affects brand loyalty 
(Chaudhuri \& Holbrook, 2001, 2002). Consumers' loyalty to the brand, which is the subject of negative information, may cause them to resist such information (Ahluwalia et al., 2000).

Various problems faced by brands (i.e., recall due to a chronic problem, racism, and sexual abuse) may cause negative information about companies and brands (Pullig et al., 2006) and lead to brand crises (Fearn-Banks, 2017: 304). Therefore, crises encountered by brands cause negative information. However, emotional factors can affect the consumers' reaction to unfavourable information about the brand. For example, when consumers have high emotional relationships with brands or their favourite objects, resistance to negative information may arise (Eisingerich et al., 2011). Similarly, brand love is a mediator between brand trust and resistance to negative information (Turgut \& Gultekin, 2015). In this sense, the positive brand affect can increase the resistance against negative information, boosting the possible repurchase intention. In this sense, the following hypothesis is formed:

H5. The impact of brand trust on repurchase intention is mediated by two mediators of brand affect and resistance to negative information.

The model of the study with the proposed hypotheses is given in Figure 1.

\section{Figure: 1}

\section{Proposed Model}

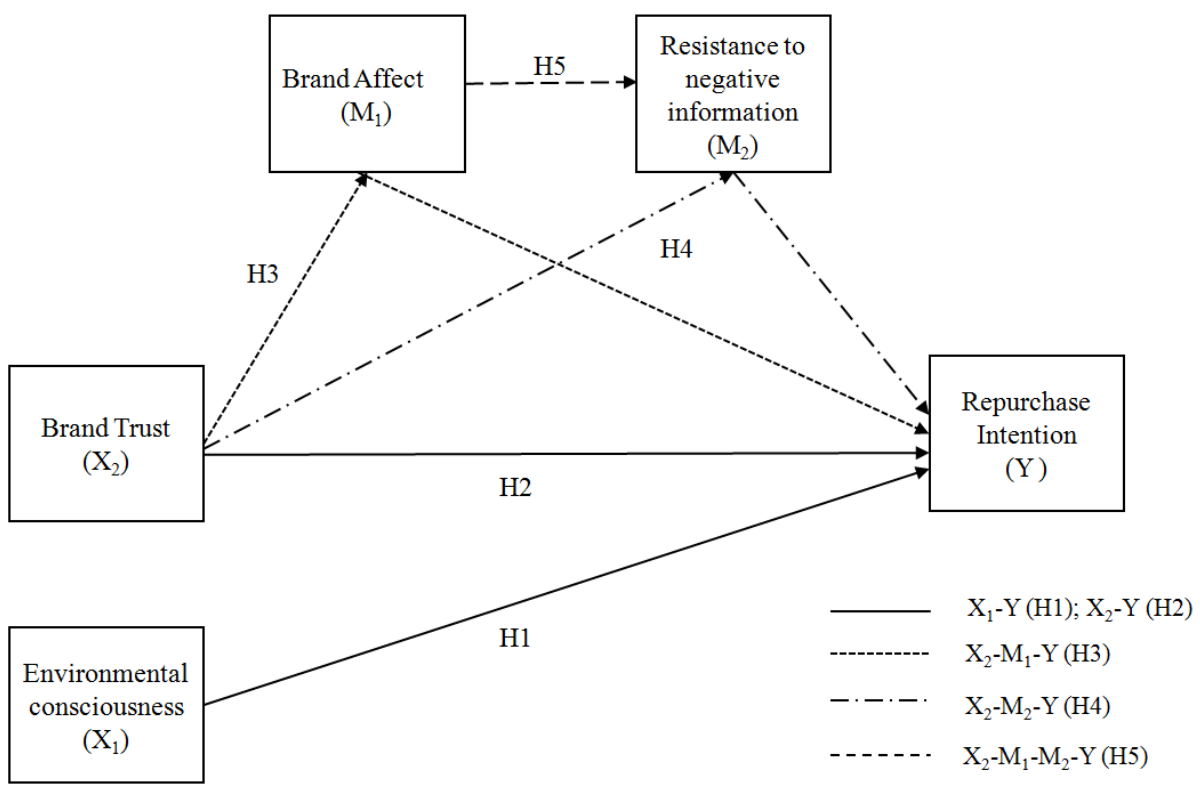


Gültekin, B. \& S.İ. Kılıç (2022), "Repurchasing an Environmental Related Crisis Experienced Automobile Brand: An Examination in the Context of Environmental Consciousness, Brand

Trust, Brand Affect, and Resistance to Negative Information", Sosyoekonomi, 30(51), 241-260.

\section{Methodology}

\subsection{Sampling}

The research data were gathered through a convenience sampling method from 110 participants living in Ankara who were actively using an automobile brand that had previously faced a crisis. The participants were asked on a nominal scale (Yes/No) whether they were using the X-branded automobile and whether they were aware of the particular environmental crisis in a specified time. Participants who marked "Yes" for both statements were included in the research sample. The brand name of this automobile is not stated for ethical reasons. The average age of the participants is 31 years, and approximately $80 \%$ are men. Furthermore, $60 \%$ of the participants stated that they are university graduates, and $70 \%$ are middle-income.

\subsection{Measures}

To measure environmental consciousness, environmentally friendly purchasing behaviour, knowledge, recycling behaviour and political action dimensions of the scale were adapted from the study of (Bohlen et al., 1993: 422-425).

The environmentally friendly product purchasing behaviour dimension includes seven items (i.e., "Choose the environmentally-friendly alternative regardless of price", "Try to discover the environmental effects of products prior to purchase") related to the frequency of purchase. These items were measured with a 5-point Likert-type scale as "Never" (1), "Always" (5) (Bohlen et al., 1993: 419). The 11 items within the environmental knowledge (i.e., knowledge about the "sea/river pollution", "global warming", "pollution from pesticides/insecticides") were utilized (Bohlen et al., 1993: 419). For the items within the knowledge dimension, a 5-point Likert-type scale with "Know nothing about" (1), "Know a great deal about" (5) was used (Bohlen et al., 1993: 419). Environmental activities such as the level of recycling (i.e., "Recycling paper", "Recycling glass") and political action to encounter environmental issues (i.e., "Supporting environmental pressure groups," "Lobbying about green issues") are measured with eight items. For the items of this dimension, a 5-point Likert-type scale was used as "Would never do" (1), "Do often" (5) (Bohlen et al., 1993: 419).

We adapted the brand trust and brand affect scales (Chaudhuri \& Holbrook, 2001). There are four items in the brand trust scale (i.e., "I trust this brand", "I rely on this brand"). For these statements, a 5-point Likert-type scale was used as "Strongly Disagree" (1), "Strongly Agree" (5), and three items in the brand affect (i.e., "I feel good when I use this brand", "This brand makes me happy") (Chaudhuri \& Holbrook, 2001: 87).

The scale of resistance to negative information was adapted from the study of Eisingerich et al. (2011). There are four items on the scale (i.e., "Negative information about [company name] does not change my general view of the firm", "Negative information about 
[company name] has no effect on me") (Eisingerich et al., 2011: 66). For these statements, a 5-point Likert-type scale was used as "Strongly Disagree" (1), "Strongly Agree" (5).

The repurchase intention scale is adapted from the study of (Chiu et al., 2012). There are three statements on the scale (i.e., "If I could, I would like to continue using [company name]," "I plan to continue using [company name] in the future) (Chiu et al., 2012: 844). For these statements, a 5-point Likert-type scale was used as "Strongly Disagree" (1), "Strongly Agree" (5).

Before the questionnaire, a voluntary participation form was presented to inform the participants about the study and get permission for their participation. Participation in the study was voluntary. Participants could quit filling out the questionnaire for any reason. In addition, common method variance was not concerned relying on Harman's one-factor test (Podsakoff \& Organ, 1986) due to the most prominent factor having just $25.84 \%$ of the variance, which is less than $50 \%$.

\subsection{Analyses}

Confirmatory Factor Analysis (CFA) assessed whether the data fit the environmental consciousness scale of three dimensions: environmentally friendly purchasing behaviour, environmental knowledge, and recycling behaviour and political action. CFA revealed an acceptable model fit after modifications due to low factor loadings (Environmentally friendly purchasing behaviour-Item 1 and Recycling and Political Action- Item 7 and Item 8) $(\chi 2=340.760$, d.f. $=225, \chi 2 /$ d.f. $=1.514$; CFI $=0.906$; RMSEA $=0.069)$. Then the average score of each dimension is taken for further analysis.

To test the H1. and H2., structural equation modelling was conducted. In structural equation modelling, to assess the study's validity, the measurement model was run with the variables Results firstly show unacceptable fit $(\chi 2=228.459$, d.f. $=109, \chi 2 /$ d.f. $=2.096$; $\mathrm{CFI}=0.918$; RMSEA $=0.100$ ). Making the related modifications, acceptable model fit is achieved $(\chi 2=162.559$, d.f. $=106, \chi 2 /$ d.f. $=1.534 ; \mathrm{CFI}=0.961 ; \mathrm{RMSEA}=0.070)$. All the factor loadings are high and statistically significant (Anderson and Gerbing 1988) and range between 0.62-0.92. Cronbach's Alpha, Average Variance Extracted (AVE) and Composite Reliability (CR) values and other descriptive statistics are given in Table 1.

Table: 1

Mean, Standard Deviation and Correlations of the Variables

\begin{tabular}{|c|c|c|c|c|c|c|c|c|c|c|}
\hline Variables & Mean & $\begin{array}{c}\text { Std. } \\
\text { Dev. }\end{array}$ & Cronbach's Alpha & $\mathrm{CR}$ & AVE & 1. & 2. & 3. & 4. & 5. \\
\hline 1. Environmental Consciousness & 3.42 & .64 & .77 & .78 & .54 & .73 & & & & \\
\hline 2. Brand Trust & 4.07 & .72 & .89 & .88 & .66 & .10 & .81 & & & \\
\hline 3. Brand Affect & 4.16 & .78 & .92 & .92 & .81 & .03 & $.74 * *$ & .90 & & \\
\hline 4. Resistance to Negative Information & 3.21 & .94 & .90 & .88 & .66 & .18 & $.53^{* *}$ & $.43 * *$ & .81 & \\
\hline 5. Repurchase intention & 3.89 & .85 & .80 & .92 & .80 & .15 & $.63^{* *}$ & $.70^{* * *}$ & $.44 * *$ & .89 \\
\hline
\end{tabular}

** $p<0.01$; Std. Dev.: Standard Deviation; CR: Composite Reliability; AVE: Average Variance Extracted; Dioganal axis represents the square root of $A V E$. 
Gültekin, B. \& S.İ. Kılıç (2022), "Repurchasing an Environmental Related Crisis Experienced Automobile Brand: An Examination in the Context of Environmental Consciousness, Brand

Trust, Brand Affect, and Resistance to Negative Information", Sosyoekonomi, 30(51), 241-260.

Cronbach's Alpha and Composite Reliability (CR) values are above 0.70, stating the reliability of the scales. Average Variance Extracted (AVE) values are above 0.50 (Fornell \& Larcker, 1981), and the square root of each scale's AVE value is greater than its highest correlation with other scales. Thus, discriminant validity is established.

Path analysis revealed that brand trust positively affects the repurchase intention of the same brand $\left(\beta=.77, \mathrm{p}<.001, \mathrm{R}^{2}=.61\right)$. However, environmental consciousness did not have any significant impact on repurchase intention $(\beta=.13, \mathrm{p}>.05)(\chi 2=178.044$, d.f. $=111$, $\chi 2 /$ d.f. $=1.604 ; \mathrm{CFI}=0.954 ; \mathrm{RMSEA}=0.074)$. Therefore, $\mathrm{H} 2$ is supported whereas $\mathrm{H} 1$ is not.

Then, mediator roles of the brand affect (M1) and resistance of negative information (M2) in the relationship between the brand trust and repurchase intention are simultaneously tested with the brand trust-brand affect-resistance to negative information-repurchase intention link via process analysis (Model 6). The study uses 5000 bootstrapping samples and $90 \%$ Confidence Interval process analysis. The results of the analysis revealed that brand affect $(\mathrm{b}=.44$, Boot S.E. $=0.10,90 \%$ CI $[.27, .62])$ is a mediator between the brand trust; repurchase intention and resistance to negative information $(b=.07$, Boot S.E. $=0.04,90 \%$ CI $[.004, .16])$ have a mediating role in the relationship between the brand trust and repurchase intention since confidence interval levels (upper-lower) does not include zero. Accordingly, $\mathrm{H} 3$ and $\mathrm{H} 4$ are supported.

On the other hand, the brand trust-brand affect-resistance to negative informationrepurchase intention linkage is not statistically significant since there is 0 between lowerlevel and upper-level confidence intervals $(b=.007$, Boot S.E. $=0.02,90 \%$ CI $[-.01, .04])$. Thus, H5 is not supported. The analysis results are presented in Table 2.

Table: 2

\section{Regression-Based Analysis Results for Mediating Roles of Brand Affect and Resistance to Negative Information on the Relationship between Brand Trust and Repurchase Intention}

\begin{tabular}{|c|c|c|c|c|}
\hline & $\mathrm{b}$ & SE. & $\mathrm{t}$ & $\mathrm{p}$ \\
\hline \multicolumn{5}{|l|}{ Direct and Total Effects } \\
\hline Brand Trust $\rightarrow$ Repurchase Intention & .74 & .08 & 8.57 & .00 \\
\hline Brand Trust $\rightarrow$ Brand Affect & .80 & .06 & 11.71 & .00 \\
\hline Brand Affect $\rightarrow$ Repurchase Intention & .55 & .10 & 5.02 & .00 \\
\hline Brand Affect $\rightarrow$ Resistance to Negative Information & .08 & .14 & .56 & .57 \\
\hline Brand Trust $\rightarrow$ Resistance to Negative Information & .63 & .15 & 3.97 & .00 \\
\hline Resistance to Negative Information $\rightarrow$ Repurchase Intention & .11 & .07 & 1.58 & .11 \\
\hline Indirect effects & Boot b/ $\beta$ & Boot S.E. & Boot LLCI & Boot ULCI \\
\hline Brand Trust $\rightarrow$ Brand Affect $(\mathrm{M} 1) \rightarrow$ Repurchase Intention & $.44 / .37$ & .10 & .27 & .62 \\
\hline Brand Trust $\rightarrow$ Resistance to Negative Information (M2) $\rightarrow$ Repurchase Intention & $.07 / .06$ & .04 & .004 & .16 \\
\hline Brand Trust $\rightarrow$ Brand Affect (M1) $\rightarrow$ Resistance to Negative Information (M2) $\rightarrow$ Repurchase Intention & $.007 / .006$ & .02 & -.01 & .04 \\
\hline
\end{tabular}

$b:$ unstandardized coefficient, $\beta$ : standardized coefficient, SE: Standard error of unstandardized estimate, LLCI: Low level confidence interval, ULCI: Upper-level confidence interval; M1: Mediator 1; M2: Mediator 2. 
Gültekin, B. \& S.İ. Kılıç (2022), "Repurchasing an Environmental Related Crisis Experienced

Automobile Brand: An Examination in the Context of Environmental Consciousness, Brand

Trust, Brand Affect, and Resistance to Negative Information”, Sosyoekonomi, 30(51), 241-260.

\section{Conclusion and Discussion}

Even the automobile brand had an environmental crisis recently, the first hypothesis (H1) that proposed direct negative impact of environmental consciousness on repurchase intention is insignificant. The participants' environmental consciousness (EC) level is slightly above the average $\left(\bar{X}_{\mathrm{EC}}=3.42\right)$. However, participants' environmental consciousness has no impact on their repurchase intention in a crisis involving the environment. In other words, although the environmental consciousness of the participants is above the average, this is not sufficient to reduce their repurchase intentions. This result is similar to the result of Özer, Kement, and Gültekin (2015), which state that the attitude towards visiting green hotels is not a determinant of revisiting these hotels. Furthermore, for those who actively drive green cars and potential green car users, the environmental impacts of green cars come after features such as price, brand, and engine power (Chowdhury et al., 2016).

The automobile subject to this research is in the category of shopping goods. According to Sriram and Forman (1993), consumers care less about the product's environmental impact than convenience goods in their shopping good purchasing process. Therefore, the failure to support the negative relationship between environmental consciousness and the intention to buy again within the brand crisis framework may be because the product discussed in this study is a shopping good. For this reason, instead of environmental consciousness, the variable of brand trust is at the forefront in the repeat purchasing intentions of the participants.

The second hypothesis (H2) that proposes the positive impact of brand trust on repurchase intention is significant. This result is consistent with commitment-trust theory (Morgan \& Hunt, 1994) and is similar to the results of other studies (Fang et al., 2011; Garbarino \& Johnson, 1999; Lin et al., 2011; Turgut \& Gultekin, 2015; Zboja \& Voorhees, 2006) examining the effect of trust on repeat purchasing intention. According to the results of this study, it can be concluded that brand trust has more priority than environmental concerns and sensitivities.

The third, fourth, and fifth hypotheses examine the link between brand trustrepurchase intention within the mediators' framework. The third hypothesis is supported; brand trust positively affects the repeat purchasing intention of consumers through the brand affect. The fourth hypothesis is supported; brand trust positively affects the repeat purchasing intention of consumers via resistance to negative information.

McKenzie (2019), Nielsen's Global Intelligence Leader, states that it is impossible to regain brand trust when it is damaged; when brand trust is established, the brand trust provides essential benefits for companies. The data obtained from this study also show that trust (BT) in the brand that has experienced a crisis is high $\left(\bar{X}_{\mathrm{BT}}=4,07\right)$. This finding shows that brand trust acts as a shield after the brand crisis and positively affects repeat purchasing intention by supporting the brand affect and creating resistance to negative information. 
Gültekin, B. \& S.İ. Kılıç (2022), "Repurchasing an Environmental Related Crisis Experienced Automobile Brand: An Examination in the Context of Environmental Consciousness, Brand

Trust, Brand Affect, and Resistance to Negative Information", Sosyoekonomi, 30(51), 241-260.

Brand trust positively affects repeat purchasing intention through brand affect after the crises (H3). As the participants trust in brand increases, brand affect boosts which in turn positively influences their purchase intentions. Brand affect is an essential concept for companies. Namely, the emotional reactions arising from consumers' experiences towards the brand create the brand affect (Orzan et al., 2016). This study found that the participants of this study have a positive brand affect $(\mathrm{BA})\left(\bar{X}_{\mathrm{BA}}=4,16\right)$. For example, more than $80 \%$ of the participants responded positively to the items measuring the brand affect, such as liking the brand and favouring the brand. There are studies showing that brand affect is a precursor to brand loyalty (Matzler et al., 2006; Nezakati et al., 2013; Ong et al., 2012). The repeat purchase intention of the consumers in a brand experiencing a crisis might be due to brand trust via brand affect.

Furthermore, brand trust positively affects repeat purchasing intention through resistance to negative information (H4). This result is similar to Turgut and Gultekin (2015)'s study, which found that brand trust positively affects resistance to negative information. Accordingly, this study emphasizes the importance of brand trust, which relies on the consumers' belief that the brand has competencies such as consistency, honesty, and taking responsibility (Delgado-Ballester \& Munuera-Alemán, 2005).

Based on this information, relying on brand trust, customers believe in the brand's honesty, ability to take responsibility, and resist negative information about the brand. More specifically, the annual sales of some automobile companies that experience a brand crisis are increasing year by year after the brand crisis (Reuters, 2019), which might be due to this brand trust and resistance to negative information.

However, the fifth hypothesis (H5) is not supported; brand trust- brand affectresistance to negative information-repurchase intention link is insignificant. In other words, the impact of the first mediator (brand affect) on the second mediator (resistance to negative information) is not significant. Most of the effect is brand trust-brand affect-repurchase intention relationships and then from brand trust to resistance to negative information and resistance to negative information to repurchase intention. Similarly, Chaudhuri, Holbrook (2001: 82) mention, "overall, we view brand trust as involving a process that is well thought out and carefully considered, whereas the development of brand affect is more spontaneous, more immediate, and less deliberately reasoned in nature". Relying on this perspective, brand affect and resistance to negative information are not sequential mediators but two separate mediators between brand trust and repurchase intention linkage. In other words, brand affect does not positively impact the resistance to negative information. This finding differs from Turgut and Gultekin (2015) study in which brand love positively affects resistance to negative information. Turgut and Gultekin (2015) examined brand love and resistance to negative information within the framework of clothing brands. Customers do not consider the brand affect in products such as automobiles in the context of resistance to negative information. Although brand affect has a positive effect on word-of-mouth communication activities for brands (Kabadayi \& Koçak-Alan, 2012; Westbrook, 1987), in 
Gültekin, B. \& S.İ. Kılıç (2022), "Repurchasing an Environmental Related Crisis Experienced

Automobile Brand: An Examination in the Context of Environmental Consciousness, Brand

Trust, Brand Affect, and Resistance to Negative Information”, Sosyoekonomi, 30(51), 241-260.

this study, brand affect did not provide an effect on resistance to negative information. The relationship between brand affect and resistance to negative information is explicitly evaluated for a brand that has experienced a crisis. The finding that the brand affect does not have an impact on resistance to negative information reflects that brand trust is still necessary after the crisis. It makes sense for companies to invest in longer-term issues such as brand trust to develop resistance to negative information, which increases the likelihood of repurchase intention.

\section{Managerial Implications}

All brands might encounter a crisis (Priporas \& Vangelinos, 2008) that is considered both a threat and an opportunity (Okay \& Okay, 2014: 382). The influence of environmental consciousness on the purchase intention that has experienced a crisis is not significant. However, consumers' attention to environmental-related features might be different. Consumers may resist negative information emerging against brands they consider environmentally responsible (Eisingerich et al., 2011). In addition, the activities of companies that benefit the environment (e.g., reducing greenhouse gas emissions) can positively affect the intention of consumers to purchase these products (Hartmann \& Apaolaza-Ibáñez, 2012). For example, Swedish consumers also attach importance to the greenhouse gas emission factor in their car purchase decision (Chowdhury et al., 2016).

Managers need to emphasize brand-customer relations in the pre-crisis period and their importance during and after the crisis. Therefore, in crisis management and the reactions of company managers during the crisis, the trust they have built before the crisis is also of critical importance. Trust arises from the mutual expectations of both sides to believe in each other (Matzler et al., 2008). Companies must show an honest approach that will strengthen and not threaten the trust for companies to create brand trust. Examples such as keeping the promises, the consistency and accuracy of the statements made, the transparency that is shown in crises, and taking responsibility for the mistake/s, if any, are critical in maintaining the established trust and relationship. Furthermore, brand trust enables the belief that the brand to perform as expected. To ensure brand trust, the products offered by the brand must be equal to or more than the consumer expectations (Orzan et al., 2016).

Businesses do not only focus on selling and making a profit but also to make an effort by making investments to establish long-term relationships with consumers and develop brand equity (Morgan \& Hunt, 1994). Among these efforts, there are various social responsibility projects for the environment. At the same time, businesses claim that they are environmentally friendly in their advertising messages (Shrum et al., 1995), recently some of the automobile advertisements include $\mathrm{CO}_{2}$ emissions released. In an environment where environmental issues gain such importance, companies' ignoring the environment and environmental problems in their marketing strategies can cause several consequences that may cause the company to lose millions of dollars and, at the same time, damage their reputation (Dauvergne \& Lister, 2012). Since customers continue paying attention to 
environmental problems, companies should invest in the company's trust and reputation. However, the environmental consciousness does not affect their intention to repurchase the brand that has experienced a crisis.

Brand trust positively affects repurchase intention through brand affect and resistance to negative information. However, in this process, brand affect does not have an impact on resistance to negative information. Therefore, expressions related to brand affect after the crisis do not mean that customers will resist negative information. Therefore, in the context of brand affect and resistance to negative information relationships, firms' emphasis on brand trust may be more beneficial for a brand that has experienced a crisis.

Similarly, considering the findings of this study, the effect of brand trust on repeat purchase through brand affect is greater than the effect of brand trust through resistance to negative information in terms of repurchase intention. For this reason, it is vital to give messages about brand trust and emphasize the brand affect on the marketing communication activities of the company after the crisis period.

\section{Limitations and Recommendations for Future Research}

This study has constraints in terms of method and variables. First, the results of the study are limited to the sample obtained. In addition, in future studies, the comparative analysis could consider the users of different automobile brands that have encountered a crisis. This research discusses the customers' perceptions regarding the automobile being considered a shopping good. Therefore, examining subsequent studies by considering the crisis of convenience, speciality, or unsought goods may contribute to the literature.

One of the research variables, resistance to negative information, is a new concept in recent years. This research examines the concept with environmental consciousness, brand trust, and brand affect. Since the negative information affects the consumers' purchasing behaviour (Ahluwalia et al., 2000; Eisingerich et al., 2011), future studies might investigate the adverse effect of the resistance to negative information on the company's sales. For example, when consumers are exposed to negative information about a product, they may qualify for poor quality. In contrast, positive information does not affect consumers' classification of products in this way (Ahluwalia et al., 2000). According to Ahluwalia et al. (2000), consumers can obtain positive information about the products more frequently and easily. For this reason, future studies can discuss the effects of resistance to negative information about brands that have experienced a crisis on the perceived quality of products and consumers' purchasing decision process.

In future studies, the proposed model can be tested in different countries. In addition to these, future studies can address the impact of corporate social responsibility activities of brands experiencing a crisis in the context of resistance to negative information and repurchase intention. There are studies in the literature on the moderating role of environmental consciousness (Garvey \& Bolton, 2017; Lin et al., 2015; Russell \& Russell, 
Gültekin, B. \& S.İ. Kılıç (2022), "Repurchasing an Environmental Related Crisis Experienced Automobile Brand: An Examination in the Context of Environmental Consciousness, Brand Trust, Brand Affect, and Resistance to Negative Information”, Sosyoekonomi, 30(51), 241-260.

2010). It is crucial to consider the moderating role of environmental awareness within the framework of the brand crisis in future studies. Furthermore, the study of Garvey and Bolton (2017) reveals that the environmental consciousness level has a moderating effect on the relationship between environmentally friendly product selection and environmental behaviour. In this context, in future studies, an environmentally friendly car (e.g., an electric car) that has experienced a crisis in the past can be examined within the model's scope in this study.

\section{References}

Aaker, J. et al. (2004), "When good brands do bad", Journal of Consumer Research, 31(1), 1-16.

Abratt, R. \& D. Sacks (1988), "The marketing challenge: Towards being profitable and socially responsible", Journal of Business Ethics, 7(7), 497-507.

Ahluwalia, R. et al. (2000), "Consumer response to negative publicity: The moderating role of commitment", Journal of Marketing Research, 37(2), 203-214.

Ariffin, S. et al. (2016), "Factors Influencing Perceived Quality and Repurchase Intention Towards Green Products", Procedia Economics and Finance, 37, 391-396.

Barney, J.B. \& M.H. Hansen (1994), "Trustworthiness as a Source of Competitive Advantage", Strategic Management Journal, 15(S1), 175-190.

Bohlen, G. et al. (1993), "Measuring ecological concern: A multi-construct perspective", Journal of Marketing Management, 9(4), 415-430.

Carter, T. (1997), “Crisis management for sales force managers”, Journal of Professional Services Marketing, 15(2), 87-103.

Chaudhuri, A. \& M.B. Holbrook (2001), "The chain of effects from brand trust and brand affect to brand performance: The role of brand loyalty", Journal of Marketing, 65(2), 81-93.

Chaudhuri, A. \& M.B. Holbrook (2002), "Product-class effects on brand commitment and brand outcomes: The role of brand trust and brand affect", Journal of Brand Management, 10(1), 33-58.

Chen-Yu, J. et al. (2016), "Brand perception and brand repurchase intent in online apparel shopping: An examination of brand experience, image congruence, brand affect, and brand trust", Journal of Global Fashion Marketing, 7(1), 30-44.

Chevalier, J.A. \& D. Mayzlin (2006), "The effect of word of mouth on sales: Online book reviews", Journal of Marketing Research, 43(3), 345-354.

Chiu, C.M. et al., (2012), "Re-examining the influence of trust on online repeat purchase intention: The moderating role of habit and its antecedents", Decision Support Systems, 53(4), 835845.

Chowdhury, M. et al. (2016), "Consumer preferences and policy implications for the green car market”, Marketing Intelligence and Planning, 34(6), 810-827.

Claeys, A.S. et al. (2010), "Restoring reputations in times of crisis: An experimental study of the Situational Crisis Communication Theory and the moderating effects of locus of control”, Public Relations Review, 36(3), 256-262. 
Gültekin, B. \& S.İ. Kılıç (2022), "Repurchasing an Environmental Related Crisis Experienced Automobile Brand: An Examination in the Context of Environmental Consciousness, Brand Trust, Brand Affect, and Resistance to Negative Information", Sosyoekonomi, 30(51), 241-260.

Daly, A. \& P. Zannetti (2007), “An Introduction to Air Pollution - Definitions, Classifications, and History”, in: P. Zannetti et al. (Eds.), Ambient Air Pollution (1-14), The Arab School for Science and Technology (ASST) and The EnviroComp Institute.

Dauvergne, P. \& J. Lister (2012), "Big brand sustainability: Governance prospects and environmental limits", Global Environmental Change, 22(1), 36-45.

Dawar, N. \& J. Lei (2009), "Brand crises: The roles of brand familiarity and crisis relevance in determining the impact on brand evaluations", Journal of Business Research, 62(4), 509516.

Dawar, N. \& M.M. Pillutla (2000), "Impact of product-harm crises on brand equity: The moderating role of consumer expectations", Journal of Marketing Research, XXXVII(May), 215226.

Delgado-Ballester, E. \& J.L. Munuera-Alemán (2001), "Brand trust in the context of consumer loyalty", European Journal of Marketing, 35(11/12), 1238-1258.

Delgado-Ballester, E. \& J.L. Munuera-Alemán (2005), "Does brand trust matter to brand equity?", Journal of Product and Brand Management, 14(3), 187-196.

Delgado-Ballester, E. et al. (2003), "Development and validation of a brand trust scale", International Journal of Market Research, 45(1), 35-54.

Eisingerich, A.B. et al. (2011), "Doing good and doing better despite negative information?: The role of corporate social responsibility in consumer resistance to negative information", Journal of Service Research, 14(1), 60-75.

Fang, Y.H. et al. (2011), “Understanding customers' satisfaction and repurchase intentions: An integration of IS success model, trust, and justice", Internet Research, 21(4), 479-503.

Fearn-Banks, K. (2017), Crisis communications: A casebook approach (Fifth), New York: Routledge Taylor \& Francis.

Garbarino, E. \& M.S. Johnson (1999), "The different roles of satisfaction, trust, and commitment in customer relationships", Journal of Marketing, 63(April), 70-87.

Garvey, A.M. \& L.E. Bolton (2017), "Eco-product choice cuts both ways: How proenvironmental licensing versus reinforcement is contingent on environmental consciousness", Journal of Public Policy and Marketing, 36(2), 284-298.

Grönroos, C. (1997), "From marketing mix to relationship marketing - towards a paradigm shift in marketing", Management Decision, 35(4), 322-339.

Hartmann, P. \& V. Apaolaza-Ibáñez (2012), "Consumer attitude and purchase intention toward green energy brands: The roles of psychological benefits and environmental concern", Journal of Business Research, 65(9), 1254-1263.

Kabadayi, E.T. \& A. Koçak-Alan (2012), "Brand Trust and Brand Affect: Their Strategic Importance on Brand Loyalty", Journal of Global Strategic Management, 6(1), 80-88.

Kalafatis, S.P. et al. (1999), “Green marketing and Ajzen's theory of planned behaviour: A crossmarket examination", Journal of Consumer Marketing, 16(5), 441-460.

Kang, J. et al. (2021), "Felt betrayed or resisted? The impact of pre-crisis corporate social responsibility reputation on post-crisis consumer reactions and retaliatory behavioral intentions", Corporate Social Responsibility and Environmental Management, 28, 511524. 
Gültekin, B. \& S.İ. K1lı̧ (2022), "Repurchasing an Environmental Related Crisis Experienced Automobile Brand: An Examination in the Context of Environmental Consciousness, Brand Trust, Brand Affect, and Resistance to Negative Information”, Sosyoekonomi, 30(51), 241-260.

Kong, W. et al. (2014), “The Influence of Consumers' Perception of green Products on Green Purchase Intention”, International Journal of Asian Social Science, 4(8), 924-939.

Krause, D. (1993), "Environmental Consciousness: An Empirical Study”, Environment and Behavior, 25(1), 126-142.

Laroche, M. et al. (2012), "The effects of social media based brand communities on brand community markers, value creation practices, brand trust and brand loyalty," Computers in Human Behavior, 28(5), 1755-1767.

Lin, C.P. et al. (2011), "Understanding Purchase Intention During Product-Harm Crises: Moderating Effects of Perceived Corporate Ability and Corporate Social Responsibility", Journal of Business Ethics, 102(3), 455-471.

Lin, C.P. et al. (2015), "Forecasting the purchase intention of IT product: Key roles of trust and environmental consciousness for IT firms", Technological Forecasting and Social Change, 99, 148-155.

Liu, Y. (2006), "Word of mouth for movies: Its dynamics and impact on box office revenue", Journal of Marketing, 70(3), 74-89.

Matzler, K. et al. (2006), "Individual determinants of brand affect: The role of the personality traits of extraversion and openness to experience", Journal of Product and Brand Management, 15(7), 427-434.

Matzler, K. et al. (2008), "Risk aversion and brand loyalty: The mediating role of brand trust and brand affect", Journal of Product and Brand Management, 17(3), 154-162.

McKenzie, S. (2019), Trust: If you break it, you might lose it forever. But if you get it right, it pays you back, <https://www.linkedin.com/feed/update/urn:li:activity:6554498077468749824/>, 05.29 .2021 .

Menon, A. et al. (1999), "Evolving Paradigm for Environmental Sensitivity in Marketing Programs: A Synthesis of Theory and Practice", Journal of Marketing Theory and Practice, 7(2), 115.

Mishra, M.K. et al. (2016), "The relationship between risk aversion, brand trust, brand affect and loyalty: Evidence from the FMCG industry", Journal of Indian Business Research, 8(2), 78-97.

Mitroff, I.I. et al. (1987), "Effective Crisis Management", The Academy of Management Executive, 1(4), 283-292.

Morgan, R.M. \& S.D. Hunt (1994), “The Commitment-Trust Theory of Relationship Marketing”, Journal of Marketing, 58(July), 20-38.

Newholm, T. \& D. Shaw (2007), "Studying the ethical consumer: a review of research", Journal of Consumer Behaviour, 6(5), 253-270.

Nezakati, H. et al. (2013), “Antecedents impact on brand loyalty in cosmetics industry", Journal of Applied Sciences, 13(1), 126-132.

North, N.S. (2011), Social media's role in branding: A study of social media use and the cultivation of brand affect, trust, and loyalty, University of Texas at Austin, <https://repositories.lib.utexas.edu/handle/2152/ETD-UT-2011-12-4924>,11.08.2021.

Okay, A. \& A. Okay (2014), Halkla ilişkiler kavram ve strateji uygulamalarl (Public relations concepts and strategy applications) (7th ed.), İstanbul: Der Yayınları (Der Publishing). 
Gültekin, B. \& S.İ. Kılıç (2022), "Repurchasing an Environmental Related Crisis Experienced Automobile Brand: An Examination in the Context of Environmental Consciousness, Brand

Trust, Brand Affect, and Resistance to Negative Information", Sosyoekonomi, 30(51), 241-260.

Ong, F.S. et al. (2012), "Path analysis of atmospherics and convenience on flow: the mediation effects of brand affect and brand trust", International Review of Retail, Distribution and Consumer Research, 22(3), 277-291.

Orzan, G. et al. (2016), "Conceptual model regarding the influence of social media marketing communication on brand trust, brand affect and brand loyalty", Economic Computation and Economic Cybernetics Studies and Research, 50(1), 141-156.

Özer, L. et al. (2015), “Genişletilmiş Planlanmış Davranış Teorisi Kapsamında Yeşil Yıldızlı Otelleri Tekrar Ziyaret Etme Niyeti”, HÜ IIIBF Dergisi, 33(4), 59-85.

Pace, S. et al. (2017), "The effects of social media on brand attitude and WOM during a brand crisis: Evidences from the Barilla case", Journal of Marketing Communications, 23(2), 135148.

Park, S.-Y. \& S.W. Lee (2013), "Effects of a perceived brand crisis on product evaluation and purchase intention: the moderating roles of brand credibility and brand attachment", Journal of Global Scholars of Marketing Science, 23(2), 213-226.

Peltekoğlu, F.B. (2014), Halkla ilişkiler nedir? (What is Public Relations?), (8th ed.), İstanbul: Beta Basım Yayım Dağıtım.

Podsakoff, P.M. \& D.W. Organ (1986), "Self-Reports in Organizational Research: Problems and Prospects", Journal of Management, 12(4), 531-544.

Priporas, C.V. \& G. Vangelinos (2008), "Crisis management in pharmaceuticals: Evidence from Greece", International Journal of Pharmaceutical and Healthcare Marketing, 2(2), 88102.

Prothero, A. (1990), "Green consumerism and the societal marketing concept: Marketing strategies for the 1990's", Journal of Marketing Management, 6(2), 87-103.

Pullig, C. et al. (2006), "Attitude basis, certainty, and challenge alignment: A case of negative brand publicity", Journal of the Academy of Marketing Science, 34(4), 528-542.

Reuters (2019), Volkswagen delivered 10.8 million vehicles in 2018, eyes world No.1 spot, <https://www.reuters.com/article/us-volkswagen-sales/volkswagen-delivered-10-8million-cars-in-2018-eyes-world-no-1-spot-idUSKCN1P5111>, 29.05.2021.

Russell, D.W. \& C.A. Russell (2010), "Here or there? Consumer reactions to corporate social responsibility initiatives: Egocentric tendencies and their moderators", Marketing Letters, 21, 65-81.

Schlegelmilch, B.B. et al. (1996), "The link between green purchasing decisions and measures of environmental consciousness", European Journal of Marketing, 30(5), 35-55.

Shrum, L.J. et al. (1995), "Buyer characteristics of the green consumer and their implications for advertising strategy", Journal of Advertising, 24(2), 71-82.

Souiden, N. \& F. Pons (2009), "Product recall crisis management: The impact on manufacturer's image, consumer loyalty and purchase intention", Journal of Product and Brand Management, 18(2), 106-114.

Sriram, V. \& A.M. Forman (1993), “The Relative Importance of Products' Environmental Attributes: A Cross-cultural Comparison”, International Marketing Review, 10(3), 51-70.

Takas, A. (1974), “Societal Marketing: A Businessman's Perspective”, Journal of Marketing, 38(4), 2-7. 
Gültekin, B. \& S.İ. Kılıç (2022), "Repurchasing an Environmental Related Crisis Experienced Automobile Brand: An Examination in the Context of Environmental Consciousness, Brand Trust, Brand Affect, and Resistance to Negative Information”, Sosyoekonomi, 30(51), 241-260.

Turgut, M.U. \& B. Gultekin (2015), “The Critical Role of Brand Love in Clothing Brands”, Journal of Business, Economics \& Finance, 4(1), 126-152.

Upamannyu, N.K. et al. (2015), "Effect of Corporate Image on Brand Trust and Brand Affect", International Journal of Appied Science-Research and Review, 2(1), 20-33.

Westbrook, R.A. (1987), "Product/Consumption-Based Affective Responses and Postpurchase Processes", Journal of Marketing Research, 24(3), 258-270.

Yannopoulou, N. et al. (2011), "Media amplification of a brand crisis and its affect on brand trust", Journal of Marketing Management, 27(5-6), 530-546.

Zboja, J.J. \& C.M. Voorhees (2006), "The impact of brand trust and satisfaction on retailer repurchase intentions”, Journal of Services Marketing, 20(5), 381-390. 